\title{
A Note on the Effects of a Product of Aspergillus niger on Nuclei of Allium cepa
}

\author{
F. B. Kulfinski and A. J. Pappelis \\ Department of Biological Sciences, Southern Illinois University, Edwardsville 62026, \\ and Department of Botany, Southern Illinois University, \\ Carbondale 62901, U.S.A.
}

Received November 21, 1978

An avirulent Aspergillus niger van Tiegh. reduced nuclear dry mass (NDM) of cells of Allium cepa L. 0-5 mm ahead of mycelium by $11 \%$ in comparison with normal cells 15-20 mm ahead (Kulfinski and Pappelis 1971, 1976, Kulfinski et al. 1973). The fungus penetrated host tissue by less than $1 \mathrm{~mm}$, few cells were killed in advance of mycelium and only a very narrow watery lesion was produced. In contrast, virulent $A$. niger isolated from an infected white onion bulb produced wide watery lesions, killed cells in advance of mycelium, and reduced NDM of cells $0-5 \mathrm{~mm}$ ahead of mycelium by approximately $40 \%$ (Kulfinski and Pappelis 1976, Kulfinski and Pappelis 1978, Kulfinski et al. 1973). We inferred that $A$. niger secreted a toxic substance into host tissue and that, if the amount of this substance varied with the fungal isolate, then this substance might be responsible for differential virulence. The purpose of this study, therefore, was to test the hypothesis that $A$. niger will also produce this toxic substance in vitro. We wished to produce the substance in quantity as a prelude to pathogenicity, purification and characterization studies. We recognized the possibility that different toxic substances might accumulate in vivo and in vitro; however, we proceeded on the premise that the same substance would be produced. Nuclear degeneration and cell death in squares of epidermal tissues $5 \mathrm{~mm}$ on a side were used to assay for presence and effectiveness of fungal product.

\section{Materials and methods}

Virulent $A$. niger isolated from white onion was cultured in Czapek-Dox broth (500 ml per $1500 \mathrm{ml}$ Ehrlenmeyer flask) on a reciprocating shaker at 90 excursions per minute under ambient cool-white fluorescent lighting for 7 days at $23^{\circ} \mathrm{C}$. The spent culture medium was sterilized by filtration through a $0.04 \mathrm{~nm}$ porosity filter. Two adjacent squares of tissue $5 \mathrm{~mm}$ on a side were removed from the equatorial region of the third turgid bulb scale of each of six white onions measuring $10 \mathrm{~cm}$ in diameter. One square was placed in distilled water and the second in culture filtrate. After incubation under ambient laboratory conditions for a period of 15 minutes, each square was recovered and its adaxial epidermis was mounted in distilled water. A cover slip was added and ringed with paraffin oil to prevent evaporation. Average optical path difference per nucleus was determined by means of a Leitz interference microscope using light of $546 \mathrm{~nm}$, and converted into dry 
mass per unit area (DM/A) using $\alpha=0.0018$ (Beneke 1966). Nuclei were photographed, negatives projected, and nuclear images traced. The tracings were measured by means of a planimeter and converted to nuclear area (NA). DM/A and NA were multiplied to yield nuclear dry mass (NDM).

A modification of the Luyet (1937) neutral red staining technique was used for determining cell death. Onion epidermis was immersed in a $0.5 \%$ aqueous solution of neutral red and then mounted in water and examined microscopically. In our experience with living cells, cytoplasm remained colorless, whereas intact vacuoles stained rose-red. Cells were defined as dead when the vacuolar membrane lost its integrity, at which time the sharp distinction between cytoplasm and vacuole disappeared and both became orange in color. This is consistant with the "moment of cell death" as defined by Bessis (1964). Following cytoplasmic death, the nucleus often became red, whereas it remained colorless in live cells. Neutral red differential stainability correlated with ability to plasmolyze. Epidermal strips were immersed for $15 \mathrm{sec}$ in culture filtrate and the percent viable cells was determined using neutral red stainability. No differences were found in percent viable cells between cells incubated in distilled water or those incubated in fresh nutrient broth as controls.

\section{Results and discussion}

Neutral red staining and plasmolysis studies showed that $50 \%$ of the live cells in stripped epidermis were killed by a $15 \mathrm{sec}$ immersion in culture filtrate.

When pieces of epidermis were incubated in culture filtrate for $15 \mathrm{~min}$, all cells were killed. Very few cells were killed in controls (distilled water or Czapek-Dox broth). The killing effectiveness of the culture filtrate was not diminished after $15 \mathrm{~min}$ boiling followed by cooling to $23^{\circ} \mathrm{C}$. Epidermal cells incubated in filtrate for $15 \mathrm{~min}$ decreased by $31 \%$ in NA and $29 \%$ in NDM, whereas the DM/A remained essentially unchanged (Table 1). NA and NDM of individual cells were not well correlated

Table 1. Characteristics of nuclei of control and culture filtrate treated onion epidermal cells. $\mathrm{NA}=$ nuclear area in $\mathrm{cm}^{2} \times 10^{-\mathrm{B}}, \mathrm{DM} / \mathrm{A}=$ dry mass per unit area in $\mathrm{g} / \mathrm{cm}^{2} \times$ $10^{-5}$ and $\mathrm{NDM}=$ nuclear dry mass in $\mathrm{g} \times 10^{-10}$. Each value is a mean of 60 nuclei among 6 replicates

\begin{tabular}{lccc}
\hline & \multicolumn{3}{c}{ Nuclear characteristics } \\
\cline { 2 - 4 } Treatments & NA & DM/A & NDM \\
\hline Control & 8.7 & 12.4 & 10.4 \\
Filtrate & $6.0^{a}$ & 12.3 & $7.4^{a}$ \\
F/C Percent & 69 & 99 & 71 \\
\hline
\end{tabular}

a Characteristics so marked are significantly different from their respective controls, at the $95 \%$ level of probability.

in either control or filtrate-treated tissue, the correlation coefficients being $r=0.38$ and $r=0.26$, respectively.

The rapid killing of stripped host epidermal cells by culture filtrate and the 
reduction in NA and NDM were accompanied by the development of a watersoaked appearance of bulb scale tissue and generalized development of minute vacuoles (bubbling) within the cytoplasm of these cells. These symptoms are comparable to those in onions infected with $A$. niger, particularily just ahead of advancing hyphae. We infer that both symptoms are attributable to a toxic substance produced by this pathogen. Narain and Prakash (1968) reported finding that $A$. niger isolated from onion produced a thermostable toxin in culture. Khazaradze (1960) stated that the first morphological changes in onion tissue infected with $\mathrm{BO}$ trytis allii appear in nuclei and postulated the production of toxic substances by that pathogen. Kulfinski, et al. (1973), and Kulfinski and Pappelis (1976) demonstrated that $B$. allii and virulent $A$. niger produce similar nuclear degeneration. $B$. allii reduced NDM by $41 \%$ and virulent $A$. niger reduced NDM by $42 \%$.

Our data confirm the presence of a toxic factor in $A$. niger culture filtrate and suggest that it operates at the level of the nucleus. Since similar damage is produced by virulent $A$. niger infection as by its culture filtrate, we cannot reject the hypothesis that the same toxic factor is involved in producing the damage in each case.

\section{Abstract}

A heat stabile substance was produced by $A$. niger, accumulated in the culture medium, and induced nuclear area and nuclear dry mass decreases in inner epidermal cells of onion bulb scales comparable to decreases observed $0-5 \mathrm{~mm}$ ahead of mycelium in infected bulbs. When tissue squares $5 \mathrm{~mm}$ on a side were incubated in culture filtrate, half of the cells were dead after 15 seconds incubation and all were dead in 15 minutes. Because the effects of infective mycelium and culture filtrate were comparable in kind of nuclear changes produced and similar in magnitude of these changes, we suggest that the same substance was produced by the fungus in vitro as during infection.

\section{Literature cited}

Beneke, G. 1966. Application of interference microscopy to biological material. In Introduction to Quantative Cytochemistry (G. L. Wied ed.), pp. 63-92, Academic Press, New York. Bessis, M. 1964. Studies on cell agony and death: an attempt at classification. In Cellular Injury (A.V.S. de Reuck and J. Knight eds.), pp. 287-316, Little, Brown and Co., Boston.

Khazaradze, E. P. 1960. A cytophysiological study of onion infected by gray mold. Trud. Inst. Zashch. Rast. Akad. Nauk Gruz S. S. R. 13: 196.

Kulfinski, F. B. and Pappelis, A. J. 1971. Interference microcsopy of onion epidermal nuclei in response to three fungal pathogens. Physiol. Plant Path. 1: 489-494.

- and - 1976. The use of quantative interferometry in the study of epidermal tissue. In Microbiology of Aerial Plant Surfaces (C. H. Kickinson and T. F. Prece eds.), pp. 637-657, Academic Press, London.

- and - 1978. Appropriate control tissues for host-pathogen studies in onion. Cytologia 43: 411-414.

-, - and Pappelis, G. A. 1973. The effects of Botrytis allii and Aspergillus niger on nuclei of onion bulb scale epidermis. Shokubutsu Byogai Kenkyu (Forsch. Gebiet Pflanzenkrankh.) Kyoto 8: 103-114. 
Luyet, B. J. 1937. Differential staining for living and dead cells. Science 85: 106.

Narain, A. and Prakash, O. 1968. Toxic metabolite of Aspergillus niger and its role in onion rot disease. Indian Phytopath. 21 : 217-220. 